\title{
Metáfora, belleza y contemporaneidad en el ámbito del culto
}

\author{
Metaphor, beauty and contemporaneity in the sphere of worship
}

Mercé Gambús Saiz, Victoriano Sainz Gutiérrez, Soledad García Morales, Luigi Leoni y Javier Viver Gómez

Sábado, 14 de noviembre de 2009

https://doi.org/10.17979/aarc.2009.2.1.5044

\section{MERCÉ GAMBÚS}

Como es la mesa redonda que va cerrar estas tres jornadas, y como creo que el sentir de gran parte de las personas que han asistido a este congreso ha sido que han tenido pocas ocasiones de participar, vamos a intentar que sea éste el momento adecuado. Han sido muchos los temas que han salido a colación, y no soy yo la persona encargada de sintetizarlos. Pero en todo caso, les voy a hacer ustedes una especie de flash de ideas que han ido saliendo. Por ejemplo, el espacio arquitectónico sagrado como activador de la experiencia sagrada. Binomios tales como la relación metáfora-símbolo, templo-iglesia, arquitectura-urbanismo o funcionalismo-liturgia.

Me voy a interrumpir aquí para recordar a los que asistieron al primer congreso - y ahora a los que están en este segundo congreso- de que en el primer congreso salimos todos de aquí tal día como hoy diciendo: el programa es la liturgia. No digo que entonces comulgáramos necesariamente con esta frase, pero en estas sesiones quizá se haya lanzado la reivindicación de la arquitectura. La arquitectura, y a partir del análisis de los problemas, se hablaba de un análisis funcional radical.

Pero yo no voy a insistir mucho más: naturaleza, arquitectura, liturgia, son muchos de los temas adecuados, pero también hay otras miradas que convergen, como por ejemplo $-\mathrm{y}$ hemos tenido ocasión de comprobar estos días hasta qué punto el arquitecto como director de orquesta está comprometido con el problema- en el caso de la liturgia y en el caso del culto, con las imágenes. La doctora García Morales, de la Universidad Politécnica de Madrid, decía que reivindicaba la comunión de los santos. En términos precisamente de recuperar el tema de las imágenes. Hoy - y es algo que me ha encantado - alguien ha citado a Compagnon y los antimodernos: es otra cita, yo creo, extraordinaria.

Pero en fin, no voy a ser yo la que me voy a alargar, porque si no sería completamente incoherente. ¿Cómo dialogan la arquitectura y las imágenes en la definición del arte o del espacio sacro contemporáneo? Lenguajes, técnicas, materiales, procedimientos... la iconicidad de la imagen sagrada a través de los episodios narrativos, de los episodios cultuales, rituales, el mundo del mobiliario, el mundo del vitral, el mundo de los objetos litúrgicos, el mundo de la indumentaria, la síntesis de las artes. ¿El arquitecto pude alejarse o de algún modo desocuparse de los problemas de la iconicidad en el espacio sacro? ¿Cómo dialogan, cómo debaten?

Aún les voy a decir algo más. ¿Qué ocurre con las nuevas imágenes y con las imágenes históricas en los edificios nuevos y en edificios históricos que hay que conservar? Porque se ha hablado muy poco del patrimonio histórico. El patrimonio histórico habrá que intervenirlo, y no siempre se tratará de consolidaciones, 


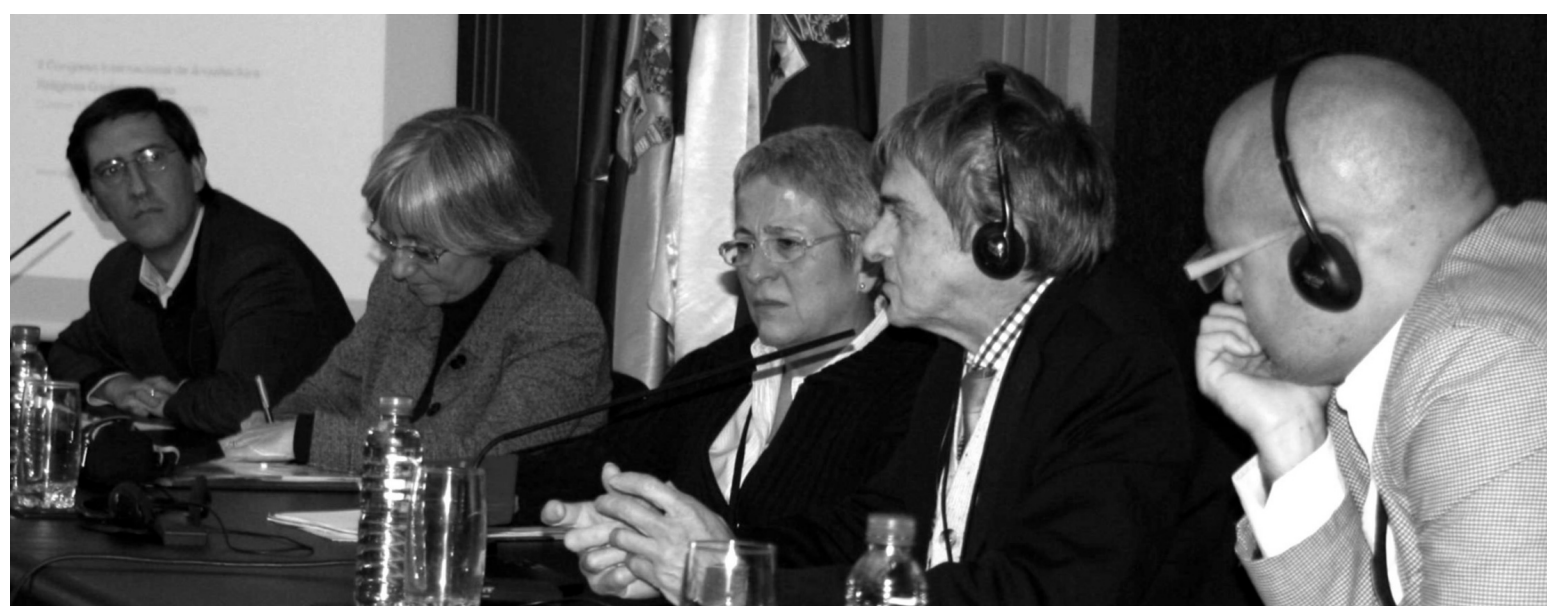

Victoriano Sainz, Soledad García Morales, Mercé Gambùs (moderadora) Luigi Leoni y Javier Viver.

ni de simples reconstrucciones. En algún momento, ese nuevo lenguaje deberá entrar en ese viejo espacio. En fin, mi experiencia me indica que ahí, en el territorio de la iconicidad, ya está el debate. Y pienso que una plataforma como la que se ha desarrollado en estos tres días de congreso, con un tema tan especializado y con un nivel como el alcanzado, constituye un foro excelente para debatirlo. A continuación intervendrá la doctora Soledad García Morales.

\section{SOLEDAD GARCÍA MORALES}

Siguiendo en la línea que la profesora Gambús nos ha iniciado, yo sólo voy a aportar preguntas. Porque se trata de suscitar el debate, y de dar la palabra a los que realmente pueden opinar sobre esto.

Yo, como primera pregunta diría: ¿Tiene que existir una verdadera unión en cuanto a entrelazamiento, pero ya desde el aspecto proyectual, entre la arquitectura y las artes plásticas, o la arquitectura ha de constituir una peana donde se va a sostener luego una imagen? Esa es una primera pregunta. ¿Cómo profundizamos en eso? ¿Debe el arquitecto abrir su fase creativa y de diseño e integrar todas las artes plásticas ahí? Yo no voy a dar mis respuestas todavía. Segunda pregunta: ¿es el paisaje un icono? Porque aparece en las propuestas de Richard Neutra, de Tadao Ando y de otros arquitectos. ¿Es el paisaje un icono en sí mismo, o debemos trans- mutarlo como nos sugería Costantino Ruggeri? ¿De qué manera hacemos eso hoy en día? Esta es la segunda pregunta. La tercera pregunta: si el paisaje no se trasmuta, ¿serían únicamente Jesucristo, la Virgen María y los santos las imágenes que tenemos que representar? Porque antiguamente los programas iconográficos se referían a la Historia Sagrada, a imágenes que movieran a la piedad, etc. Hay un programa iconográfico riquísimo, pero nosotros ¿sobre qué tenemos que centrarnos? ¿Tenemos que recuperar el papel de las imágenes sagradas en la catequesis, como en el Románico por ejemplo, o tenemos que fomentar solamente imágenes para la oración, que tendrían otra contextualización distinta? Esta es otra pregunta. Y finalmente, mi última pregunta -que es únicamente intencional, porque yo tengo mi respuesta para esto- es: ¿Imágenes estáticas o móviles? ¿Deberíamos introducir con fuerza el videoarte como una nueva modalidad plástica en nuestras iglesias? ¿De qué manera lo haremos? Estas son mis preguntas. A ver si con esto conseguimos que hable todo el mundo.

\section{LUIGI LEONI}

Pienso que el problema del vínculo entre la arquitectura y las artes plásticas — pintura, escultura- es un vasto problema que a mí me ha preocupado mucho, precisamente porque es difícil encontrar una solución 
única. El arquitecto, en general, está preparado para aportar fuerza a un espacio sacro, y cuando llega a la conclusión de su trabajo, demanda la inserción de elementos escultóricos (en el altar, en la sede del presidente, en el lugar de la palabra), y también demanda a otros artistas trabajos para la conclusión de la obra.

El padre Costantino era diferente, en general, porque concebía la obra en su totalidad. Aceptaba al principio la colaboración con otros artistas, llegando a una comunión con ellos. Era un trabajo difícil, porque se requiere una gran unidad, una comunión profunda de espíritu, de corazón. Las mismas tensiones que llevan a compartir la obra hacen que se sienta una gran unidad, porque el peligro, al final, es que la arquitectura quiera decir una cosa y las intervenciones posteriores digan otra.

Es cierto que hay algunas exigencias inexcusables, como aquellas vinculadas a las devociones que deben introducirse en la iglesia, con las estatuas para la piedad popular, etc. Pero no es sólo esto. Es dar un rostro, una caracterización a los elementos fundamentales que entran a formar parte del espacio sagrado; que verdaderamente sean uno con la arquitectura. En algunos de los ejemplos contemporáneos que veíamos hoy [de Dom van der Laan] se ha llegado a la pureza absoluta de estos elementos. No siempre es así. Se siente la necesidad, en algunos espacios que no son auténticos, de introducir lo que le falta a la arquitectura: elementos plásticos ricos. Pero no sólo ricos por su fuerza expresiva, sino ricos de tantas cosas que se necesitan. Cuando no es, según mi opinión, la complejidad de las imágenes que nosotros introducimos, imágenes que pueden hablar verdaderamente al corazón del hombre. Es la profundidad.

Es cierto que ya la misma arquitectura debe tener su discurso, debe hablar de imágenes. Pero la arquitectura se proyecta desde imágenes que tal vez no sean reconducibles a imágenes descifrables inmediatamente. Hemos visto aquí hoy [en la ponencia de Soledad García Morales] cuánto hay en lo profundo de nuestro corazón de aspiraciones, de sueños: todo en un corazón que, de cualquier modo, exprime las imágenes. Las imágenes fuertes hablan a nuestro corazón de un modo misterioso. No sabemos por qué una obra ha tenido ciertos resultados. Cuando hablaba el arquitecto Gresleri, nos decía que son los milagros los que intervienen. Milagros que proceden de la consonancia de muchos factores y que no se sabe cómo vienen. En un cierto momento histórico, en un cierto lugar preciso, hay un encuentro particular de personas - hoy, aquí, hay un encuentro particular de personas - : los sacerdotes comitentes, el obispo de la diócesis, el arquitecto, jla comunidad parroquial!

Se requiere una síntesis para producir un único impulso, una única tensión, en la cual tendrían que poder entrar - aunque no hayan estado en el momento inicial - todos aquellos artistas que verdaderamente se sientan una sola cosa con todos aquellos que trabajan dentro de este edificio sacro - discutiendo, por supuesto, durante el largo avance de las obras- - . No puede un artista ser llamado, por ejemplo, para hacer el vía crucis en una pared sin haber podido compartir todo el proceso de adquisición del espacio: cómo ha sido generado, cómo ha sido pensado. ¿Como se puede pensar sólo en atender a un muro aislado sin tener en cuenta la totalidad de una arquitectura, todo lo que un artista piensa? Porque yo creo que es un proceso verdaderamente apasionante, que aunque necesita ese aliento, sin embargo no debería cerrarse a una investigación que se convierte para el futuro en bellísima, estupenda, porque abre, de verdad, las miradas. Pensad - al ver las obras de esta mañana, por ejemplo - que nadie se atrevería a acometer algunas obras sin ver, sin contar, con la contribución de tantos.

He comentado con Giorgio della Longa que una de mas cosas que me parecen más bonitas de este congreso es el hecho de encontrarse para compartir nuestras experiencias. Así se abre nuestro corazón, que produce cosas estupendas que sólo sabe él. Y crea para el hombre espacios, y acondiciona estos espacios para que inviten a la oración, a la alegría, a la paz, para que inviten a la comunión, y para que, sobre todo, hagan sentir ese misterio de la comunión entre el hombre y Dios.

\section{VICTORIANO SAINZ}

A ver, brevísimamente. Sólo querría subrayar dos asuntos que han salido ya. Ayer, cuando yo presentaba a Van der Laan, decía que él entendía que, en la liturgia cristiana, lo que es un signo es la liturgia como un todo. En ese sentido, coincido con que hace falta ese dialogo entre la Iglesia como comitente, el arquitecto y los artistas que intervienen para producir ese espacio sacro; y que después también hace falta sintonizar con la asamblea que va a participar del rito litúrgico que ahí se va a 
celebrar. Esto me parece bien. Pienso que cada uno tiene su propio papel. Evidentemente, entiendo que el papel del arquitecto y del artista es el de «hacer» el espacio sacro. Y ese papel le corresponde propiamente y creo que así ha sido a lo largo de toda la historia.

Precisamente porque creo que en esta cuestión nos encontramos inmersos en una tradición viva, comentaba hace un momento Soledad - y Javier Viver lo ponía de relieve en su intervención de esta mañana con una claridad y fuerza tremendas- que nos encontramos ante un problema. Bueno, no sé si es exactamente un problema, pero sí una cuestión que se ha presentado siempre en cada generación de la historia: ver cómo damos respuesta en esta sociedad en la que estamos viviendo, con los medios técnicos de que disponemos, con los medios artísticos de que disponemos, a construir un espacio sacro contemporáneo. Que evidentemente se inserta dentro de una tradición, pero que tiene que ser capaz de crear y de incorporar todos los medios técnicos y artísticos que tenemos, con los que estamos trabajando y que estamos explorando. Es el tema de las nuevas tecnologías en relación con las artes plásticas.

Pero anoche, durante el concierto, pensaba sobre el tema de la música. Me parece una cuestión absolutamente fundamental de cara a la construcción de la liturgia. Bueno, pienso que las cuestiones que tenemos delante en gran medida tienen que ver con esto: con cómo somos capaces - los artistas, los arquitectos- de poner nuestro granito de arena para la renovación del espacio sacro contemporáneo. Un espacio sacro contemporáneo que no solo no sea renuncia, sino que utilice como medios expresivos los medios actuales. Me parece que ese es nuestro reto, y me gustaría que esta reflexión diera también lugar a intervenciones por parte de los presentes.

\section{JAVIER VIVER}

Vamos a ver, porque se han tocado aquí muchísimos temas. Yo, en primer lugar, en relación con la integración de arquitecto y artistas, pienso que el tema es mucho más complejo. Tengo que compararlo con una producción cinematográfica. Me parece que puede ser un buen ejemplo de algo parecido a lo que supone construir una iglesia.

En el cine tiene que haber una serie de promotores, tiene que haber un alma, primero tiene que haber un productor. Y luego tiene que haber un director y una serie de actores. Y de artistas que entran y salen, y cada uno hace su papel. En definitiva, a mí me parece que la labor del arquitecto sería la del director de la película. De tal forma que el director no puede estar preocupado en cuestiones de producción, porque tiene que haber alguien que sea el que solucione esas cosas. Y eso habitualmente es tarea del comitente.

Cuando se produce una integración así aparecen unos resultados excelentes. El director, de alguna forma, tiene que descubrir los valores del actor, que puede ser en este caso el escultor, el músico o el que hace cualquier otro de los trabajos. Es una auténtica labor de dirección, y en la medida en la que se deja paso a uno o a otro artista, la arquitectura también entabla esa relación con el resto de las artes y se produce un fenómeno espectacular. Y me parece que aquí tiene mucho sentido entender la liturgia - decía Pavel Florenski- como arte total. Es un tema tremendamente de vanguardias. Yo creo que la confluencia de poesía, de música, de arquitectura, de toda la integración de las artes y los sentidos no se ha dado en ningún otro sitio con la intensidad con la que se ha dado en la iglesia. Y me parece que hay que plantearse el reto en esa dimensión.

Sobre los otros temas, por supuesto que yo estoy completamente a favor de la introducción de la imagen en movimiento dentro de la iglesia, no solamente con un carácter pedagógico, sino que llega un momento en que la catequesis se tiene que hacer mistagogía. Es decir, que a la hora de hablar del misterio no se pueden utilizar conceptos rígidos, sino que necesitamos la imagen, y por lo tanto toda imagen implica una creación. $\mathrm{O}$ sea, que para hablar de arte, para hablar de la liturgia, para hablar del misterio, necesitamos - y así ha sidola mejor pedagogía. Y esa se ha hecho desarrollando una obra de arte. Bueno, pues ahí quedan las cuestiones.

\section{MERCÉ GAMBÚS}

Antes de dar la palabra al público, sólo quiero recordar una cosa, en mi calidad de historiadora del arte. Piensen ustedes que a lo largo de la historia el edificio sacro nunca se concibió en función de la presencia de las artes plásticas. La arquitectura era, sobre todo, un contenedor. Y el contenido se iba acumulando a lo largo del tiempo. Y esto lo digo a efectos de la percepción. Y, evidentemente, hoy el arte contemporáneo tiene delante de sí un reto único, que es integrarlo todo desde el 
primer momento.

Pero también sigo insistiendo. Tengan ustedes en cuenta que en España, al menos el setenta por ciento de nuestro patrimonio histórico procede de los bienes de la Iglesia. Y ese patrimonio hay que conservarlo, y la intervención contemporánea cada vez más va a ser objeto de debate. Simplemente lo digo como reflexión para que ustedes lo tengan en cuenta. A partir de ahora tienen ustedes la palabra.

\section{CHEMA DAPENA}

En este mundo de arquitectos yo soy un artista plástico, profesor de Bellas Artes. Y respondiendo a dos preguntas que hizo Soledad, pienso que el artista plástico no es un personaje que vaya detrás del arquitecto, en este caso. El arquitecto tampoco es el poseedor de las Bellas Artes, en absoluto. El arquitecto es un elemento esencial dentro del arte, al igual que es el artista plástico. Ahora mismo me encuentro trabajando a la par con un arquitecto en una obra religiosa, y me parece el trabajo más fascinante que he hecho en mi vida. Nos somos «rellenadores» - diríamos vulgarmente- de espacios que un arquitecto nos deja. No. Es muy fácil que un arquitecto cree espacios y después diga: — ¿Qué se pone ahí? Alguien tendrá experiencia de estos casos. No somos rellenadores de espacios. Debemos ir trabajando desde el primer momento con el arquitecto.

Sólo veo un grave problema desde la historia de la arquitectura: los arquitectos casi se consideraban, sí, como los únicos poseedores de la verdad, con todo mi respeto lo digo. $\mathrm{Y}$ eran inaccesibles. El propio artista tenía que pedir por favor al arquitecto su intervención. Entonces yo consideraría tres podiums: uno central, más elevado, donde está la arquitectura; en el podio de la derecha se pone el arquitecto, en el podio de la izquierda se pone el artista plástico, y los dos se lanzan al podio central. Y de ahí, al cielo.

\section{EDUARDO DELGADO}

Bueno, intentaré ser muy breve. Soy Eduardo Delgado, arquitecto. Parece que además de cosas muy interesantes que se han planteado - Mercé, Soledad y todos los demás-, Javier ha puesto encima de la mesa la imagen de la producción cinematográfica en la que ya se ve que hay muchos actores. A mi me gustaría, si me lo permitís, dar un paso más, que sería hablar de una actualización en estas acciones, que son acciones de la
Iglesia. No son acciones de un arquitecto, ni de un artista, ni siquiera de un comitente, sino que en muchos casos deberían considerarse acciones de la Iglesia, llamadas a perdurar en el tiempo, cómo una actualización del misterio del Cuerpo Místico de Cristo, que explica muy bien San Pablo. En las que hay una cabeza, hay una mano, hay un pie y hay muchas otras partes del cuerpo, cada una de las cuales tienen su función y que no deben de interferir entre sí, aunque existe una unidad y una relación irrenunciable entre ellas. Creo que profundizar en esta imagen nos ayudaría muchísimo a entender - a mí me ayuda a entender - el misterio que significa la realización de un obra de arquitectura, qué significa un conjunto de este tipo. En el que no hay también como empezaba a apuntar Chema—, no debe haber ningún protagonista realmente. Una obra identificable por su autor es un error. En fin, esta es una idea que yo quiero subrayar.

\section{IAGO SEARA}

Una de las características más importantes —a mi modo de ver- del arte contemporáneo es que los artistas utilizan el espacio como soporte o instrumento de expresión. Pero hay otro aspecto que está siempre presente en todas las manifestaciones actuales: la memoria, la memoria histórica interpretada desde muchos puntos de vista. Y creo que estos dos aspectos conforman todo el planteamiento que tiene una comunidad eclesiástica que está construyendo su fe, su identidad; y cuenta con ello porque está presente en todas sus manifestaciones plásticas.

$Y$ la identidad es un tema que lo orienta bien un frase de John Berger, que todos conocéis. Cuando le preguntan sobre lo qué opina de la identidad, él contesta: — «Yo creo en la identidad... — debió de haber un silencio entre él y el o la periodista-: en aquella identidad que contemple todas las identidades». Esto me parece extraordinario, porque cada comunidad que construye un edificio - y por tanto construye su fe- o que ya lo construyó, realmente pone en juego unos matices excepcionales, entre los que puede haber ideas plásticas, conceptuales o cultuales, pero en los que al final siempre hay una presencia de esa comunidad. Y eso me parece muy importante. Y esa es la síntesis perfecta entre lo local y lo global. De alguna forma, católico - si no recuerdo mal- quiere decir universal, y todo ese ideal universal de alguna manera también debe 
estar presente.

Para mí, lo más importante es esa identidad que surge de la construcción de la comunidad a través de la construcción de un edificio para esa comunidad. En definitiva, yo sigo insistiendo en que todo tiene un espacio y en que todo tiene un tiempo. Y cuando explico a mis alumnos las asignaturas de restauración o de conservación, suelo decir que en la actualidad, con cualquier intervención estamos interviniendo en la historia. En una historia de alguna manera expresada por la cultura material o inmaterial. Pero cuando te encuentras con la historia te ves en la obligación disciplinar de hacer acuerdos en el tiempo, en el tiempo de hoy. Y al final, esos acuerdos conforman una forma, pero vuelvo a repetir, una forma material e inmaterial. Hoy en día no se entienden esos dos conceptos separados.

Evidentemente, los integrantes del nacionalismo histórico gallego no decían «cultura inmaterial», si no «cultura espiritual». Y lo hacían con una intención y con una comprensión de un país que además de estar humanizado, construido, está también cristianizado con petos de ánimas, cruceros, ermitas y parroquias. Nuestro Estatuto de Autonomía dice que los elementos que articulan el territorio son la aldea, la parroquia y la comarca. Pero la parroquia está ahí. Con esto quiero ordenar este debate.

Pero diré una cosa más, ya como arquitecto. Kenneth Frampton decía - y después William Curtis lo matizaba en sus planteamientos- que al adquirir esos matices locales, la arquitectura contemporánea se hizo universal. Y así se inició una tradición.

Una observación más. Ya que se citó aquí el cementerio de Módena, de Rossi, diré que la construcción de la ciudad está en transformación permanente, que el monumento transforma la ciudad, todo edificio urbano, y que el edificio construye la ciudad. Lo que quería decir el otro día es que la catedral de Santiago construyó una ciudad, construyó un territorio histórico e incluso una idea del hombre. Y a mí, estos aspectos me interesan mucho.

Pero después de decir todo esto, vuelvo a decir, lo más importante de mi experiencia personal es la construcción de dos templos, uno en Madrid y otro en Santiago, en el barrio de Fontiñas. El barrio de Fontiñas es un no-lugar y el recinto parroquial de Fontiñas es un lugar. El lugar en el que se identifican parte de los habitantes de Fontiñas es en la parroquia de San Antonio.
Hasta el punto de que el barrio nuevo, cuando instaura su fiesta, le llama la fiesta de San Antonio.

\section{STEVEN J. SCHLOEDER}

En respuesta a su pregunta $-\mathrm{O}$ a sus dos preguntas-, pienso que merecen una conferencia propia.

El primer punto del debate trata sobre la integración del arte sacro y la arquitectura. La historia de la arquitectura religiosa es la historia de la integración entre arte y arquitectura. Durante la integración del arte bizantino con el mosaico, del gótico con la escultura y las artes plásticas, en las portadas románicas, y especialmente en la era del barroco, cuando la pintura se convierte en el marco, en la pared, hay una integración arquitectónica de todas las artes. Y creo que uno de los problemas de la arquitectura moderna es que observa los objetos aisladamente. Así que colocamos un vía crucis en la pared, o ponemos un crucifijo en un gran muro en blanco. Y no hay relación entre ellos. Y la propia naturaleza de la arquitectura eclesiástica es la de construir relaciones, porque estamos expresando una relación entre Dios y la Humanidad, entre la comunidad y sus integrantes, entre la comunidad local y la comunidad de los santos. Siempre existe esa relación: este es el principio teológico que separa al cristianismo de todas las demás religiones: que estamos en relación con nuestro amado Dios, y que nosotros somos amados por Él. Por eso, me preocupa que la arquitectura moderna intente evitar esa relación entre las artes y el propio edificio, y yo animo a desarrollar dicha relación.

Para responder a la última pregunta, con respecto a Javier, tengo una gran preocupación teológica por la integración del vídeo o de las imágenes en movimiento en la liturgia. La razón es simplemente que el vídeo, la $\mathrm{TV}$, esta clase de cosas, no es que sean profanas, es que están en el cronos, están en el tiempo medible. El sentido de la liturgia es que entramos en el kayrós, que es el tiempo sagrado. La tecnología supone un problema con respecto a la arquitectura eclesiástica. $\mathrm{Y}$ digo esto con respeto, ya que todos debemos disfrutar de la acústica moderna, de la calefacción moderna, de la iluminación moderna en las iglesias. Evidentemente, la tecnología no es mala.

Pero hay un problema: Marshall McLuhan, el semiólogo canadiense, dijo que el micrófono había matado a la liturgia, y es una idea interesante. Ciertamente, la tecnología es una interrupción. Así que 
eso es lo que me preocupa. Me han ofrecido un aparato porque querían integrar una presentación de vídeo en el diseño de una iglesia, y yo lo rechacé categóricamente, dije que no. Pero es un problema que hay que considerar cuidadosamente.

\section{PARTICIPANTE NO IDENTIFICADA}

Yo soy artista plástica y trabajo exclusivamente en arte sacro. A propósito de lo que decía Luigi Leoni sobre la experiencia de la integración de las artes, yo he tenido la suerte de hacer una experiencia algo especial trabajando conjuntamente en arquitectura y artes plásticas.

Yo trabajé en un centro -el Aletti, cerca de Florencia, tal vez lo conozcan - que tiene la particularidad de hacer nacer todas las cosas de un conjunto, de una comunión de artistas plásticos. Es decir, todo proyecto nace desde el principio en conjunto, y luego resulta en una síntesis en la cual las artes plásticas no son algo «pegado» entre ellas, sino parte integrante del edificio. Y de esta manera, el edificio se convierte en arte plástica.

Sinceramente, estoy aquí muy ilusionada, porque desde el primer día me he encontrado con esta magnificencia de la arquitectura. La encuentro, de alguna manera, plástica. Les cuento sólo un detalle para ilustrarles lo que he experimentado. En esa iglesia de la que hablamos ayer [la iglesia de San Jorge, en Pamplona], en la cual hay una síntesis del espacio absolutamente esencial, se ve cómo se ha trabajado la materia, de manera que pueda expresar de forma casi orgánica la superficie. Esto la convierte en algo tan próximo a nosotros que se puede considerar totalmente plástica: pertenece a las artes plásticas. Y por eso, no veo división alguna entre arquitectura y artes plásticas, no la entiendo.

Todos estos conceptos de arquitectura me han atrapado tanto que casi han entrado en mí, por exagerar algo. He exultado tanto con la arquitectura como cuando realizo una escultura, un mosaico o un cuadro, al mismo nivel. Por eso, yo me pregunto: si el arte es una forma de expresar lo sublime, tal vez la única forma de hacer visible como se puede el alma humana, este alma contiene en sí algo místico.

Yo no veo que haya compartimentos estancos entre arquitectura y artes plásticas, ni tampoco con la danza o la música. Y me pregunto por qué no se juntan todas para exaltar a Dios, para mostrarlo, para hacerlo visible entre nosotros. Esto me parece claro, porque yo he hecho esta experiencia y he visto que es posible. En este punto quiero agradecerles a todos ustedes el haber podido participar en esta experiencia singular para todos nosotros.

\section{MERCEDES PÉREZ DEL PRADO}

Bueno, Eduardo me ha pisado muchas cosas de las que iba a decir, pero bueno, abundo en ellas.

Yo creo que cuando vamos a hacer algo que es religioso, católico, lo esencial es el espíritu de comunión. Eso, llevado a todos los ámbitos, nos hace replantearnos muchas cosas. Porque creo que, por supuesto, las cosas sagradas nos hablan de oración, nos hablan de escucha, de llenarnos de los demás y de impregnarnos de la gente que va a vivirlas. Como decía Iago, es muy importante que nos metamos en sus pieles, todos.

También, por supuesto, hay que escuchar el propio interior: eso es la contemplación y la oración. Y escuchar el lugar como paisaje, y cómo se vive ese paisaje. Puede ser un paisaje no querido o un paisaje idealizado: también ahí cuenta el cómo. Eso toca mucho la realidad de cada sitio, de cada lugar, de cada intervención.

Dentro de esa unidad en lo esencial que es la fe, que nos hace tener un denominador común, lo demás es libertad. Y el que se haya establecido una liturgia y una serie de normas especiales debe ser una ventaja. Debemos apropiarnos esas normas para que no sean un obstáculo sino todo lo contrario, un vehículo de expresión. Pienso en esa línea de integrarlo todo. Porque yo no veo ningún tipo de amenaza en integrar la modernidad y las nuevas tecnologías: todo lo contrario, creo que todo depende de cómo se usen, y de qué espíritu hay detrás de lo que se hace. Por eso, pienso que lo fundamental es tener ese espíritu dentro, para que los que estemos trabajando en esto, al final, consigamos que se haga visible el misterio.

\section{ALEKSANDAR KADIJEVIC}

Gracias, caballeros. Me gustaría hacerle una pregunta a la moderadora de esta sesión: ¿Cómo considera la relación entre el concepto y la identidad en la arquitectura eclesiástica contemporánea? ¿Es que las identidades actuales o pasadas producen, fundamentalmente, la naturaleza de estos conceptos? ¿O, por el contrario, son los conceptos independientes $-\mathrm{o}$ diferentes - los 
que deben respetar estrictamente las identidades presentes?

\section{MERCÉ GAMBÚS}

Bueno, me hace la pregunta directa a mí, cosa que me sorprende, porque se supone que yo soy una persona neutral en esta historia. Pero le contesto sin problemas.

Yo creo siempre en las relecturas como forma de progreso. Y con este le he contestado. Lo podemos ampliar después, lo digo para economizar el tiempo.

A continuación, si les parece, pienso que ha habido preguntas que han ido muy directas, otras más indirectas, pero sobre todo les pediría una cosa a todos. En los pasillos, que es cuando uno conoce más a la gente, todo el mundo dice lo mismo: qué educados somos, todos parece que decimos lo mismo, pero en realidad no estamos diciendo lo mismo. A ver si conseguimos aclarar en qué nos acercamos y en qué nos distanciamos. Tiene la palabra el que quiera responder por alusiones.

\section{JAVIER VIVER}

Vamos a ver, ya que ha salido un tema directo, intentaré responderlo. Como he tratado explicar antes, me parece que en este caso estoy de acuerdo con tu preocupación. Porque en efecto, hay que tener mucho cuidado con el tiempo; con la distancia y la inmediatez entre el tiempo sagrado y el tiempo profano. Es muy importante. La liturgia siempre ha trabajado con el tiempo, y le ha dado una cualidad distinta al tiempo profano, asumiéndolo. Creo que aquí estamos de acuerdo en el fondo de la preocupación; pero me parece que es una cuestión técnica, exclusivamente técnica, de conocimiento del medio.

Antes he puesto un ejemplo de Bill Viola. Él utiliza el recurso de la ralentización, y lo que hace la ralentización es permitir a través del cine - que es el tiempo del movimiento de los fotogramas - crear otro tiempo con el que se puede observar el tiempo profano, pero desde fuera. Esa ralentización crea el espacio contemplativo, y por lo tanto, se puede integrar dentro del espacio sagrado y de la liturgia.

Voy a poner otro ejemplo que quizá se entienda mejor. Nosotros estamos ahora realizando un taller en el que consideramos cómo el cine, a través de la aparición de los medios digitales, puede intervenir en el tiempo. Un caso muy popular que todos conocerán es el «efec- to bala» en Mátrix. Esto supone que, en un momento determinado, la cámara detiene el tiempo real, y empieza a rodear a una persona como si fuera una escultura clásica. Apolo y Dafne, que se han detenido en el tiempo. Y desde una visión eterna, fuera del tiempo, empiezas a ver todos los puntos de vista de ese momento. Lo haces desde la visión que es propia, digamos, de la eternidad, por decirlo de alguna forma, con las limitaciones que tienen todas las imágenes. Esta técnica te da la posibilidad de hablar del tiempo profano desde la eternidad y propiciar esa contemplación típicamente escultórica que es la detención del tiempo, y sin embargo, pasear en torno a un momento congelado. Son dos formas concretas en las que el tiempo se puede integrar dentro del espacio sacro.

\section{SOLEDAD GARCÍA MORALES}

Antes de nada quiero agradecerle a Steven su presencia entre nosotros, porque si hay algo de polémica en este debate es gracias a él. Creo que todavía no le hemos agradecido suficientemente el papel estupendo que está teniendo en este congreso.

Quería también incidir en esta pregunta - que en realidad son dos - sobre el hecho de ver objetos aislados sin relación con el edificio. Ese problema y el tema de tiempo que acaba de comentar Javier. Para ilustrar esto podemos recurrir al ejemplo de la Sainte-Chapelle.

Las vidrieras de la Sainte-Chapelle tienen un programa iconográfico que se adapta perfectamente al espacio, a la posición que ocupa cada vidriera dentro del templo. De tal manera que en el éste, las vidrieras representan a los profetas, porque el sol - la primera luz de la mañana- entra en el edificio a través de los profetas. A lo largo de la nave aparecen escenas de la historia de la salvación, porque la nave es la que es recorrida por el sol a lo largo del día, y se hace la similitud con la Historia de la Salvación. En el hastial oeste aparece el rosetón del Apocalipsis, que se ilumina durante la puesta del sol. Yo creo que es un caso muy paradigmático, de un momento determinado en el que el arte engloba todas las imágenes y las integra dándoles un significado único.

Lo que hay que salvar de este ejemplo no es posiblemente el que nosotros tengamos que poner vidrieras con imágenes de profetas o del Apocalipsis. No es esto. Yo creo que lo que hay que salvar es lo que el Papa Benedicto XVI apunta como el centro al cual tenemos 
que orientar todo lo que se expresa en el edificio, y es el sentido de la orientación. Orientación quiere decir y aquí toco el tema de espacio y tiempo- que en cuanto participamos en la liturgia no estamos en el presente. Estamos en un tiempo que es a la vez el tiempo pasado, el presente en el que estamos, y el lugar al que nos dirigimos. Entonces estamos reuniendo todo el tiempo en el único momento, en el que estamos celebrando, que es como si nos trasladáramos al momento de la Cruz. En ese instante estamos en el presente, recopilando la historia, y a la vez en el Calvario y dirigiéndonos al futuro. Ese sentido de tiempo cósmico que tiene que celebrar el edificio es a donde deberíamos enfocar todo. La dirección que le damos, la forma en la que introducimos la luz, la forma en la que introducimos el sonido, las imágenes, todo eso... ha de ser expresado con la potencia de nuestra arquitectura contemporánea.

No sé si esto responde a las dos preguntas. En ese sentido, yo apostaría claramente por todas las posibilidades que el arte contemporáneo nos ofrece, siempre que se retome lo que constituye el punto clave. No se si esto es una respuesta, pero es un postulado.

\section{VICTORIANO SAINZ}

Simplemente completar, quizá en un sentido, lo que ha dicho Soledad, con lo que estoy completamente de acuerdo. Vamos a ver. A mí me parece que lo que la tradición occidental ha incorporado a ese discurso dentro de la constitución sobre el arte sacro - que creo que es un discurso común a la liturgia católica y al espacio sacro en general, y que tiene que ver con lo que esta mañana comentaba Javier acerca de esa transición que Guardini denominaba «el paso de la imagen de culto a la imagen de veneración»- es la incorporación de lo ordinario, es decir, de las realidades en las que nos encontramos inmersos todos los días. Y eso es, me parece, lo que ha caracterizado al arte sacro cristiano de Occidente, distinguiéndolo respecto a la reorientación del arte cristiano en Oriente. Y eso creo que tenemos que seguir haciéndolo.

En ese contexto, estoy de acuerdo también con Javier en que comprendo el problema. Porque efectivamente existe, como existió un problema y hubo un debate fortísimo en el siglo XVI cuando en las pinturas de Rafael, en alguna de sus mejores obras, era perfectamente reconocible quien era la modelo que había servido para pintar aquella Virgen. Pero me parece que exis- tiendo todos esos problemas, tenemos que saber reflexionar sobre cómo incorporar todos los medios técnicos y las posibilidades que tenemos a nuestro alcance, precisamente para hacer un arte sacro que sea capaz de recoger en él -e incorporar, por lo tanto, a ese proceso de salvación que se realiza en la liturgia - la realidad ordinaria en la que hoy, el siglo XXI, vive la sociedad. Que será un proceso largo que tenga que ir purificando determinados elementos o viendo cómo se lleva a cabo, no tengo ninguna duda, pero pienso que la reflexión está ahí y es lo que nos toca hacer.

\section{IAGO SEARA}

La orientación este-oeste es el eje que nos marca el espacio cosmológico de la sala. Vamos a ver, tengo que decir que quedé muy, muy impresionado por la exposición de Javier y por las reflexiones que nos hizo. Y apoyándome en lo que dije antes de que hoy el arte coge al espacio como soporte de expresión, hay un tema sobre la identidad que puede tener la Iglesia ibérica, española, que frecuentemente se olvida. Y que son las manifestaciones del culto —entendido en el sentido más amplio del término - en nuestra historia. Entonces no había cine, pero había teatro, y se incorporaban en ese lugar sagrado los nacimientos vivientes, las pasiones vivientes... Y como miembro del ICOMOS, pude participar en los estudios preliminares e informes para declarar el Misterio de Elche como Patrimonio Inmaterial de la Humanidad .

Yo creo que esa libertad de espíritu, esa amplitud de culto y de experiencia son extraordinarias. Y que se pueden abrir otras manifestaciones como las que nos ha planteado Javier. Creo que esa libertad es la libertad propia de construir una fe, la libertad de una comunidad. Esta es la riqueza de lo que decía John Berger: la identidad, por supuesto. Primero somos universales, somos católicos. Yo creo que no se ha hablado con orgullo del templo católico y pienso que hay que hacerlo: de la catedral católica y del templo católico. Y en este sentido, las experiencias expuestas a modo de inventario o catálogo me parecen importantísimas. Javier, muchas gracias.

\section{BERNARDO MIRANDA}

Mi nombre es Bernardo Miranda, arquitecto de Lisboa. Quería decir que me voy con muchas cosas para pensar. Creo que en ese espacio se pueden perseguir 
diferentes aproximaciones al tema de la liturgia.

Se ha hablado mucho de Bolonia y también de la contribución de Dom Van Der Laan. Pero se ha hablado poco de precariedad, de pobreza y de las conexiones que podemos hacer y sentir entre pobreza, caridad y belleza. Pero esa pobreza y precariedad son también una señal del Nuevo Testamento, donde se puede descubrir algo que yo creo que no encontramos en una arquitectura muy suntuosa. Ayer, a propósito de la comunión de los santos, se hablaba mucho de la fiesta. Nosotros sabemos que vivimos en un mundo todavía muy injusto, un mundo muy necesitado de Jesús. Jesús, que no tenía casa alguna, que no tenía un punto fijo, que todavía se reunía con las comunidades. O sea, existe también una idea de movilidad, una idea de movimien- to. Las artes plásticas, sobre todo, proponen cuestiones sobre la dimensión de la injusticia. Tenemos que dejarnos interrogar, y por eso, yo no creo en una arte plástica que duda en el espacio que lo marca, sino en una arte plástica que está en el espacio en cuanto lo cuestiona.

Luego viene otro asunto, que son las diferentes utilizaciones del espacio, y sobre todo de lo doméstico, cotidiano, que nos ayuda a ser una comunidad mejor y no a distinguirnos de los demás. Ha sido impactante para mí la presentación del proyecto de Pamplona. Pero yo me quedo con muchas dudas sobre si esa es mi fe, si ese es verdaderamente el modelo, el icono del Jesús de hoy, del siglo XXI. Tengo muchas dudas todavía. Quería también agradecer esto, porque me voy con muchas más preguntas de las que tenía cuando llegué. 
